\title{
Gerald James Larson: A Scholar's Scholar, Beginning to End
}

\author{
Francis X. Clooney ${ }^{1}$
}

Published online: 21 October 2019

(C) Springer Nature Switzerland AG 2019

It is rare that a scholar has a very clear insight into the timing of the fruition and conclusion of his or her career and life's work. But Gerry Larson certainly did. On a panel on one-birth and many-births to which I was respondent at the AAR in 2016, when he was nearly 80 , he began his presentation with remarks on the brevity of life, recognizing even how he himself, nearing 80, had already lived almost as long as anyone could expect. And at the end of his remarks, he added, "It is perhaps possible simply to accept the idea that my one single life is hardly just an isolated event in time but, rather, that I am in a great company of companions, many of whom are nearly identical to myself, who have made my life possible and that what I do with my life will have profound implications in the lives who come after me in countless generations to come. I must take responsibility for the events that surround me and with which I have been involved in preceding trajectories in which I had a different name and a different behavior pattern. God has not created my life; I have through my deeds. God's grace is (anugraha) is ever-present to help me realize that!" Even as he spoke, I think, he knew his life's work was nearing its end, and he was at peace. And now, as I write this reflection, I have before me his last book, Classic Yoga Philosophy and the Legacy of Sāmkhya (Motilal Banarsidass 2018), a monumental volume of over one thousand pages. It contains the Yoga Sūtras in a new translation, as well as a new translation of Vyāsa's Bhāṣya, and Vācaspati Miśra's Tattvavaiśāradī. I am sure the volume as a whole will receive the reviews it deserves. Germane to this reflection, though, are the preface and the introduction. In the former, he recounts briefly his distinguished career as a pioneer in the modern study of Sāmkhya, and his dawning recognition, in the 1960s in New York and in Varanasi, of Sāmkhya as a most distinctive, vastly influential mode of Indian thinking. His life's mission, in a sense, was to draw our attention to Sāmkhya. He ends this lovely preface by thanking the Jain family at Motilal for their support, and with serenity recognizes it for what it is, "this final volume of mine in the $80^{\text {th }}$ year of my current rebirth!"

Francis X. Clooney

fclooney@hds.harvard.edu

1 Harvard University, Cambridge, MA 02138, USA 
The Introduction does all the necessary scholarly groundwork, and in particular shows where the Yoga Sütras and their tradition belong-firmly in the context of Sāmkhya. This reflection is not the place to review this thesis either, but only to admire the robustness and expertise of his presentation, a consolidation of many years of work. Gerry's work on Sāṃkhya, and so too on Yoga, will not fade from our memories any time soon.

Over the years, of course, Gerry was busy with all manner of smaller and larger writing projects, as his $\mathrm{CV}$ attests. At this writing, I am intrigued particularly by some of his early reviews-AK Reischauer's Meaning and Truth of Religion (as theory imposed on texts, rather than arising from research; Journal of the American Academy of Religion 1969), a volume of essays on the legacy of Mircea Eliade (as illumining the good and bad aspects of the study of religion); Journal for the Scientific Study of Religion 1970), and Gaspar Koelman's Pātañjala Yoga (as the work of a Thomist and Jesuit, who nonetheless still wrote a superb book; Philosophy East and West 1978). These early pieces show us the acuity and brilliance of a mind steeped in texts, and in Sāmkhya in particular. Formidable when he felt it necessary, Gerry always refused to compromise what we learn in scholarly study merely for the convenience of any theory or presupposition: the writing goes where the research leads. He could be hard on those whose work he reviewed - but just as unsparing in critique of his own words, theories, and past writings.

In an age when scholars less frequently study the great textual traditions and may, by choice or necessity, shift from one project to another over the decades, Gerry gives witness to the possibility and value of a curriculum vitae which returns again and again to a few great texts and a few great ideas. The last book might just as well be called Classic Yoga Philosophy and the Legacy of Sämkhya — and the Legacy of Gerald James Larson. May Gerry rest in peace.

Publisher's Note Springer Nature remains neutral with regard to jurisdictional claims in published maps and institutional affiliations. 